\section{Nigel Edward Carter}

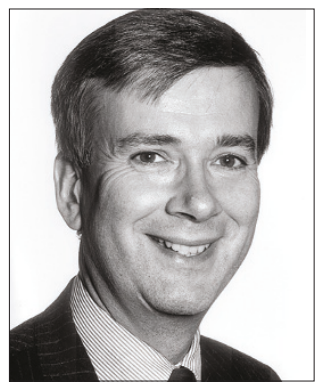

Nigel Carter was born on 3 December 1950. Qualifying from King's in 1973, he began working in general dental practice in Edenbridge in Kent. He then returned to a hospital career with house jobs at The Royal, Guy's, East Grinstead, St George's and Sheffield Dental Hospital. Nigel studied orthodontics at the Eastman and took up a consultant post at Newcastle Dental Hospital in 1988. He was also an honorary senior lecturer at the University of Newcastle, a role he took seriously, publishing books and papers. Significantly, Nigel was the training programme director for the orthodontic programme. This programme has produced the majority of orthodontic consultants and specialists from North Yorkshire across to the Lakes, up to the Scottish Border and beyond. Many thousands of patients are therefore benefiting from Nigel's teaching.

As an NHS consultant Nigel was a clinician and a team member first, a man who encouraged quiet progress rather than brash, fast achievement. As Senior Consultant he gathered his colleagues willingly around him. This manner made him a diplomat, bringing calm to the committees he sat on - and they were many - notably the

\section{Nicholas George Jackson}

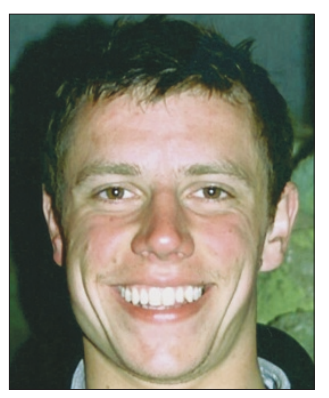

Nicholas George Jackson died on Sunday 5 June 2005 in a tragic accident. An experienced diver, he was diving with friends on an old shipwreck off the Northumbria coast when he failed to surface.

His dive boat Spellbinder reported him missing about seven miles east of Amble and an urgent request for assistance was made at 14.45. Inshore and all-weather lifeboats, several fishing boats and cargo vessels joined the search. The warship HMS Illustrious was on passage through the area and provided two Sea King helicopters to supplement a Sea King from RAF Boulmer. The lifeboats and helicopters continued until slack tide at 18.00 but failed to find any sign of him.

Born near Wigan, Lancashire in 1979, Nick went to a local primary school before attending St Mary's RC High School. He chose to apply for dentistry quite late on in Sixth Form, after work-shadowing a dentist. He observed that, in contrast to medicine, in dentistry you can have an immediate and observable effect on improving a person's wellbeing.

In 1998 Nick began his dental studies at the University of Newcastle. He enjoyed the time he spent at Newcastle greatly; including the year spent studying for his intercalated Bachelor of Medical Science degree, for which he was awarded first class honours. During that year, he was first-named author on a study that was published in the $B D J$. He went on to graduate from Newcastle dental school in 2004, gaining a distinction in restorative dentistry. He then secured a place on a two-year GPT programme based between the dental hospital in Newcastle and practice in Gateshead under the supervision of Ally Robson.

\section{Nigel was a born orthodontist: fastidious and a lover of order.}

British Dental Association Council and Council at the British Orthodontic Society, where he was secretary for the Consultant Orthodontists Group from 1999 until ill health forced him to resign in 2004.

Nigel was a born orthodontist: fastidious and a lover of order. When Nigel knew he was dying he said that he had achieved all he wanted to achieve, but his thoughts were for those he would leave behind. He leaves, most painfully, his wife Shelagh and 13-year-old son, James, who continue Nigel's active passion for choral church music, a deep love they shared together. Nigel died at home on 10 June 2005 from cancer of the kidney. He planned his own funeral, choosing the music sung so beautifully by his choir, accompanied by the Hexham Abbey organ that he so enjoyed playing in life. The packed Abbey congregation was bathed in sunlight streaming through the windows on that gloriously hot summer's day - true to form, Nigel will have organised that too!

R. Mattick

\section{He observed that in dentistry you can} \section{have an immediate and observable effect on improving a person's wellbeing.}

Throughout his life, Nick lived life to the full. An excellent swimmer, he competed at national level with his club in Wigan and then for the Newcastle University Swimming Club, winning several medals in British Universities Sports Association competitions. He learned to dive while studying at Newcastle University and was an experienced recreational diver. He loved outdoor activities and spent most free weekends hill walking in the Lake District and Scotland.

We will always regret that Nick was not allowed the time to develop his relationships, his interests and his career to the full. We are, nevertheless, thankful that his drive and energy, sometimes frustrating to those living with him, resulted in his achieving an enormous amount in 25 years. We are sure that he would have rated the past year as the happiest of his life. He at last had the time and resources to pursue his chosen interests and was successful in the career he loved.

His premature demise is a tragedy and has left a huge hole in the lives of many people: his parents Pat and George; his girlfriend Emily; his brother Matthew; and his many many other family, friends, colleagues and patients. We are at least grateful his life was happy and we think he wouldn't have wanted to change anything in the script apart from the ending.

We would like to thank everybody who shared his life and made his experiences such happy ones. 